\title{
THE MATHEMATICAL EXPRESSIONS OF QURANIC EXEGESES AND THE MATHEMATICAL DEFINITION OF THE QURANIC CORRECTNESS
}

\author{
Hiroki Tahara \\ Visiting Fellow, Hyogo Mosque \\ 5-3-15, Kamiwaka Street, Kobe, Japan \\ E-mail: taharahiroki2@gmail.com
}

\begin{abstract}
I succeeded to give mathematical expressions to any correct Quranic exegeses and define the Quranic correctness as the unique existence of Tahara I function. In a precise mathematical sense, the expressions and the definition are ill-defined however they might have meanings to prove the Quranic correctness.
\end{abstract}

Keywords: Islam and science, mathematics, Qur'an

\begin{abstract}
Abstrak: Saya memberikan ekspresi matematika terhadap tafsir Al-Qur'an dan mendefinisikan kebenaran AlQur'an sebagai keberadaan unit fungsi Tahara I. Dalam pengertian matematis, ekspresi dan pengertian tidak terdefinisi dengan baik, akan tetapi tujuannya adalah untuk membuktikan kebenaran Al-Qur'an.
\end{abstract}

Kata Kunci: Al-Qur'an, Islam dan sains, matematika

\section{Introduction}

I am a muslim because I have thought the Quran must be correct. I am a scientific fundamentalist therefore, I have thought any facts can be proved by using scientific method (Cohen, 2011; Tahara, 2019). Therefore, I have thought we can define the Quranic correctness by using truly scientific and mathematical (not far-fetched) ways like physical phenomena.

However, I have never heard such theories or studies therefore, I had wanted to discover the truly scientific and mathematical method to prove the Quranic correctness. Of course, attempts to explain the Quran logically have probably been made since the 8th century (Watt, 2014), and even in recent years, researchers such as Wahid (Wahid, 2015) tried to prove the Quranic correctness by bringing Quranic descriptions which 'seem' scientific as the evidences. I agree with the idea that the Quranic scientific descriptions are the rationales for its correctness and their studies have great meanings, however I think their interpretations of descriptions are individual and scientifically and mathematically less general (Baker, 2017).

When I learned probability theory (Ogawa, 2010) (Axler, 2020), I was inspired that any meaningful correct ways of Quranic interpretation (Lawson, 2017) (Hussin, \& Solihin, 2013) can be given expressions in mathematical map (often called 'function' (Weisstein, 2002)) forms and that the Quranic correctness can be defined by using these maps. We can prove the Quranic correctness only after defining it therefore I think this inspiration might be good for anyone who wants to prove the Quranic correctness.

In addition to this, I got an idea that there can exist only one truly correct way of Quranic interpretation, which I have thought naturally, as the sum of meaningful correct ways of Quranic interpretation if I can define the sum of maps. Therefore, I defined it and named the only one truly correct way Tahara $I$ function.

\section{A. Definitions of the basic concepts}

The conclusions are as follows:

\section{Theory 1}

Any meaningful ways of Quranic interpretation which derives true propositions can be given expressions as maps as the components of Tahara $I$ function.

\section{Theory 2}

We can define that the Quran is correct if and only if Tahara I function exists uniquely. 
In order to explain these theories, we define several other things.

1. Definitions of the special sets

Two special sets are defined as follows:

Definition 1

[Q.S.]: the Set of the Sentences of the Quran

\section{Definition 2}

[T.P.]: the Set of the Scientifically True Propositions

[T.P.] is science philosophical (Okasha, 2016). It is ill-defined (Roberts et al., 2014), therefore we need study to make it well-defined.

2. Definition of sum of maps from sets to families of sets

In this section,

$X$ is a set, $\lambda \in \Lambda, Y_{\lambda}$ is a set of sets, $f_{\lambda}: X \longrightarrow Y_{\lambda}$

and

$$
U=\bigcup S\left(S \in \bigcup_{\lambda \in \Lambda} Y_{\lambda}\right)
$$

We define the sum of maps as follows:

\section{Definition 3}

We define

$$
\sum_{\lambda \in \Lambda} f_{\lambda}=f_{1}+f_{2}+\cdots=F: X \longrightarrow U \quad \text { as } \quad F(x):=\bigcup_{\lambda \in \Lambda} f_{\lambda}(x)
$$

In particular situations, let

$$
U_{n}=\bigcup S\left(S \in \bigcup_{k=1}^{n} Y_{k}\right), U_{\infty}=\bigcup S\left(S \in \bigcup_{k=1}^{\infty} Y_{k}\right)
$$

Definition 3 means as follows:

$$
\begin{aligned}
& \sum_{k=1}^{n} f_{k}=f_{1}+f_{2}+\cdots+f_{n}=F: X \longrightarrow U_{n} \quad \text { as } \quad F(x):=\bigcup_{k=1}^{n} f_{k}(x) \\
& \sum_{k=1}^{\infty} f_{k}=f_{1}+f_{2}+\cdots=F: X \longrightarrow U_{\infty} \quad \text { as } \quad F(x):=\bigcup_{k=1}^{\infty} f_{k}(x)
\end{aligned}
$$

3. Definitions of Tahara $I$ function and its components

\section{Definition 4}

We define Tahara $I$ function as $I$ satisfied

$$
I=\sum i\left(i: 2^{[\text {Q.S. }]} \times 2^{[\text {T.P. }]} \longrightarrow 2^{[\text {T.P. }]} \wedge i \text { : meaningful }\right)
$$

the (real) components of Tahara $I$ function as $i$ satisfied

$$
i: 2^{[\mathrm{Q} . \mathrm{S} .]} \times 2^{[\text {T.P. }]} \longrightarrow 2^{[\text {T.P. }]} \wedge i \text { : meaningful }
$$

and the fake components of Tahara $I$ function as $i$ satisfied

$$
i: 2^{[\mathrm{Q} . \mathrm{S} .]} \times 2^{[\mathrm{T} . \mathrm{P} .]} \longrightarrow 2^{[\mathrm{T} . \mathrm{P} .]} \wedge i: \text { meaningless }
$$

The term 'meaningful' is mathematically ill-defined (Roberts et al., 2014). We need it to mean 'not obviously', 'not far-fetched', 'profound' and 'mathematically beautiful' (Zeki et al., 2014) (Cellucci, 2015) (Blåsjö, 2012) (Breitenbach, 2015). 


\section{B. How we can give expressions}

Interpretation means deriving its results from known facts and things whose meanings are unknown (Australia, 2013) (Hagberg, 2018). For example, when we appreciate Salvador Dalí's paintings (McNeese \& Dalí, 2006), we often interpret the paintings as follows:

[ melting clocks, burning giraffes, ... (things in the paintings) ]

$\&$

[ how the situation was when Dalís lived, the role of the clocks in the real world, ...(known facts)] $\downarrow$

[Dalís purpose of painting, ... (results of the interpretation)]

If the results are true i.e. the interpretation derives true propositions, the rationales (known facts) and results are the elements of [T.P.] alike, therefore any correct way of the interpretation of Dali's paintings can be given expression as

$$
2^{[\text {the set of the things in the paintings }]} \times 2^{[\text {T.P. }]} \longrightarrow 2^{[\text {T.P. }]}
$$

Like this, an arbitrary meaningful way of the interpretation from Quranic sentences to true propositions can be given expression as a component of Tahara $I$ function like as follows:

\section{Theoremish Expression 1}

$i$ which is a meaningful way of the interpretation from Quranic sentences to true propositions $\leftrightarrow i$ satisfied $\left[i: 2^{[\text {Q.S. }]} \times 2^{[\text {T.P. }]} \longrightarrow 2^{[\text {T.P. }]} \wedge i\right.$ : meaningful $]$ i.e. a component of Tahara $I$ function

\section{How we can define the Quranic correctness}

First, intuitively speaking, it is true that

The Quran is correct.

$\Rightarrow$ There exists at least one meaningful way to interpret Quran

which derives true propositions.

We can induct that the opposite is also true. This inference is not mathematically strict however, it is probably scientifically valid because of the beauty and the meaningfulness of the way (Dirac, 1938), (Wigner, 1990). Therefore, we can define the equivalence as follows:

\section{Lemmmawise Definition 1}

The Quran is correct.

$: \Leftrightarrow$ There exists at least one meaningful way to interpret Quran which derives true propositions.

Second, by Theoremish Expression 1, we can define another equivalence as follows:

\section{Lemmmawise Definition 2}

There exists at least one meaningful way to interpret Quran which derives true propositions $: \Longleftrightarrow \mathrm{H} i,\left(i: 2^{[\mathrm{Q} . \mathrm{S} .]} \times 2^{[\text {T.P. }]} \longrightarrow 2^{[\text {T.P. }]} \wedge i:\right.$ meaningful $)$

i.e. There exists at least one component of Tahara $I$ function. 
Third, by Definition 3 and Definition 4, the equivalence below is obviously correct.

\begin{tabular}{|c|c|}
\hline Lemmma 3 & 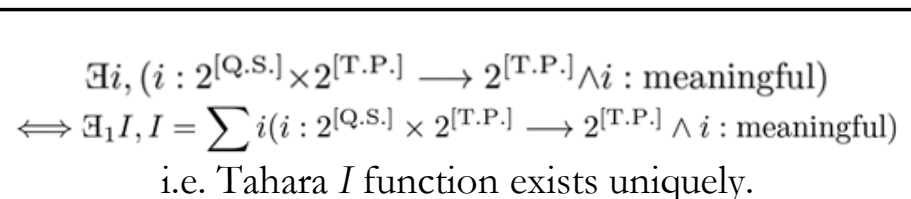 \\
\hline
\end{tabular}

By Lemmawise Definition 1, Lemmawise Definition 2 and Lemma 3, we can define the Quranic correctness as follows:

\section{Theoremish Definition 2}

Quran is correct. : $\Leftrightarrow$ Tahara $I$ function exists uniquely.

\section{Conclusion}

As I mentioned above, the conclusions are as follows: Theory 1: Any meaningful ways of Quranic interpretation which derives true propositions can be given expressions as maps as the components of Tahara $I$ function. While, Theory 2 We can define that the Quran is correct if and only if Tahara $I$ function exists uniquely.

\section{References}

Australia, I. 2013. "What is Interpretation." Recuperado de http:/ / interpretationaustralia. asn. au/ aboutia/ what-is-interpretation. Axler, S. 2020. "Probability Measures.” Measure, Integration \& Real Analysis : 380-399.

Baker, A. 2017. "Mathematics and Explanatory Generality. Philosophia Mathematica 25(2): 194-209.

Blåsjö, V. 2012. "A Definition of Mathematical Beauty and Its History. Journal of Humanistic Mathematics 2(2): 93-108.

Breitenbach, A. 2015. "Beauty in Proofs: K ant on Aesthetics in Mathematics." European Journal of Philosophy 23(4): 955-977.

Cellucci, C. 2015. "Mathematical Beauty, Understanding, and Discovery." Foundations of Science 20(4): 339-355.

Cohen, M. F. 2011. An Introduction to Logic and Scientific Method. Read Books Ltd.

Dirac, P. A. M. 1938. "The Relation between Mathematics and Physics." Proceedings of the Royal Society of Edinburgh 59(39): 122129.

Hagberg, G. L. 2018. Meaning and interpretation: Wittgenstein, Henry James, and literary knowledge. Cornell University Press.

Hussin, H., and Solihin, S. M. 2013. "Manhaj Haraki in the Revival of Quranic Exegesis." Middle-East Journal of Scientific Research 16(1): 09-17.

Lawson, T. 2017. "Structure and Quranic Interpretation: A Study of Symmetry and Coherence in Islams Holy Text." The Journal of the American Oriental Society 137(1): 215-216.

McNeese, T. and Dalí, S. 2006. Salvador Dali. Infobase Publishing.

Ogawa, T. 2010. Probability Theory. The University of Electro-Communications.

Okasha, S. 2016. Philosophy of Science: Very Short Introduction. Oxford University Press.

Roberts, J. C., et al. 2014. "From Ill-defined Problems to Informed Decisions." EuroV $A$ at EuroVis.

Tahara, H. 2019. "On the Axiomatic Methodology in Normative Ethics". Proceeding of the Social Science and Humanities Competition of the Japanese National Arts \& Science Contest 63(1): 01-23.

Wahid, P. A. 2015. The Quran: Scientific Exegesis. Islamic Science.

Watt, W. M. 2014. Islamic Philosophy and Theology. n.p: Edinburgh University Press.

Weisstein, E. W. 2002. Map. MathWorld.

Wigner, E. P. 1990. "The Unreasonable Effectiveness of Mathematics in The Natural Sciences. Mathematics and Science: 291 306.

Zeki, S., Romaya, J. P., Benincasa, D. M., and Atiyah, M. F. 2014. "The Experience of Mathematical Beauty and Its Neural Correlates. Frontiers in Human Neuroscience 8(68). 